\title{
Managing Groundwater Nitrate Contamination from Livestock Farms: Implication for Nitrate Management Guidelines
}

\author{
Prafulla Kumar Sahoo ${ }^{1,2} \cdot$ Kangjoo Kim ${ }^{2} \cdot$ M. A. Powell ${ }^{3}$
}

Published online: 26 April 2016

(C) Springer International Publishing AG 2016

\begin{abstract}
Significant nitrate contamination of groundwater has been observed in various parts of the world; intensive livestock farming is one of the major causes. This paper reviews various guidelines/regulations, which have been developed in advanced countries such as USA, Canada, Australia, and Europe to combat this problem by designing effective monitoring and management programs. Monitoring programs deal mainly with selection of sites, number of monitoring wells, specific parameters, and sampling frequency, which are helpful for identifying the source and extend of the contamination. Management programs deal with selection of suitable location, site characterization, proximity of livestock facilities and drinking wells, and proper storage, maintenance of the facilities, and limits of manures application in order to minimize nitrate leaching into groundwater. The main aim of this paper is to help states/countries, which do not have any guideline, and consulting engineers/consultants/owners of livestock operation in the design of effective strategies for point source nitrate management.
\end{abstract}

Keywords Nitrate contamination · Livestock · Groundwater . Management guidelines

This article is part of the Topical Collection on Water Pollution

Prafulla Kumar Sahoo

prafulla.iitkgp@gmail.com

1 Vale Institute of Technology, Baventura da Silva, 66055-090 Belem, Para, Brazil

2 Department of Environmental Engineering, Kunsan National University, Jeonbuk 573-701, Republic of Korea

3 Faculty of Agriculture, Life and Environmental Sciences, Department of Renewable Resources, University of Alberta, Edmonton, AB T6G 2R3, Canada

\section{Introduction}

Nitrate $\left(\mathrm{NO}_{3}{ }^{-}\right)$contamination of groundwater is a serious environmental issue of global concern because of its direct adverse effect on human health via drinking water [1-4]. Ingestion of excess nitrate in drinking water causes harmful biological effects such as methemoglobinemia, hypertension, infant mortality, goiter, stomach cancer, thyroid disorder, cytogenetic defects, and birth defects [5]. Nitrate exists in groundwater through natural processes; however, the concentration can be greatly increased from various anthropogenic sources. One of the major anthropogenic sources of nitrate contamination comes from intensive agriculture activities $[6,7]$. Other anthropogenic sources are associated with industrial wastes related to food processing, waste water treatment plants, septic tanks, and livestock facilities [8-11]. Intensive livestock farming (in which large numbers of pigs, chickens, or cows are housed together in a relatively small area) is a potential source of nitrate contamination to the surrounding surface and groundwater in many countries [12-16] and is growing as livestock production has been increased rapidly to meet increased demand for food and other products [17-19]. Most of the growth comes from industrial farms clustered around major urban cities. A joint IFPRI/FAO/ ILRI study, Livestock to 2020: The Next Food Revolution [17], noted that global meat production has risen from $233 \mathrm{Mt}$ in 2000 and is expected to reach $300 \mathrm{Mt}$ by 2020 and milk production will increase from 568 to $700 \mathrm{Mt}$ over the same 20 -year period. To meet this demand, livestock population will need to increase dramatically, along with the waste they produce.

Livestock waste contains nitrogen both in inorganic and organic compounds. The inorganic fraction is equivalent to the $\mathrm{N}$ emitted in urine and usually greater than organic one. Microbial action decomposes wastes containing organic 
nitrogen into ammonia, which is then converted into nitrite and nitrate. Nitrite is easily oxidized to nitrate, so nitrate is predominant in decomposed wastes [20] Nitrate-containing compounds in soil are generally soluble and can readily migrate through soil layers [21]. Thus, improper management of livestock waste can pose serious threats to groundwater via several pathways, such as surface runoff from farm building, improper discharge, leaking from storage facility, and excessive land application of wastes [22, 23]. Understanding of nitrate policies to control nitrate dynamics is important for managing potential groundwater pollution.

Based on the toxicity, the maximum contamination level (MCL) for drinking water has been set at $50 \mathrm{mg} / \mathrm{L}$ nitrate ion $\left(\mathrm{NO}_{3}\right)$ (equivalent to $11.3 \mathrm{mg} / \mathrm{L}$ nitrate-nitrogen, $\mathrm{NO}_{3}-\mathrm{N}$ ) by the World Health Organization (WHO), and $10 \mathrm{mg} / \mathrm{L} \mathrm{NO}_{3}-\mathrm{N}$ by the US Environmental Protection Agency (EPA) [24, 25]. The MCL for drinking water is set at $10 \mathrm{mg} / \mathrm{L}$ for nitrate plus nitrite-nitrogen $\left(\mathrm{NO}_{2}-\mathrm{N}\right)$ in Japan [1] and at $45 \mathrm{mg} / \mathrm{L} \mathrm{NO}_{3}$ in India [20]. Several countries and/or states from the USA, Canada, Australia, and Europe have developed monitoring and management guidelines or legislation to regulate nitrate contamination in groundwater or as point sources.

In this paper, we have reviewed the guidelines and regulations that have been developed in advanced countries (e.g., USA, Canada, Australia, and Europe) focusing on livestock facilities. The goal of this review is to compare these guidelines and regulations to explore suitable or best methods for reducing nitrate contamination at livestock facilities based on monitoring and management programs. Monitoring programs are used to identify potential or vulnerable zones where groundwater might be significantly degraded and/or to determine the extent of nitrate pollution plumes that threaten groundwater quality in the vicinity of a facility. Management programs aim at decreasing pollution at the origin such as livestock yard and waste storage area by implementing preventive guidelines. As such, this review is distinct, and it will be helpful to states/countries, which do not currently have guideline, and/or consulting engineers/consultants/owners of livestock operations to design appropriate guidelines/ strategies for nitrate management.

\section{Groundwater Monitoring Program}

A well-designed monitoring serves to provide a sufficient early warning that allows for corrective action if warranted. Several factors must be considered in establishing a serviceable monitoring program. These include selecting appropriate sites and sampling locations, number of samples to be monitored at each site, and frequency of sampling, among other parameters.

\section{Site Selection}

Groundwater monitoring site selection and criteria are significantly different for different parts of the world. Table 1 gives a brief outline of criteria for some of the countries such as USA, Canada, Australia, and Ireland. As this information shows, criteria are based on the size of the livestock herd, proximity to public water sources, geology, soils, well configuration, bedrock, aquifer type and position relative to soils and bedrock, total hydrogeology, and type of waste. There is no agreement nor a way to standardize these criteria into a simple way of classification. That is, the selection process must be taken on a site-to-site basis.

\section{Selection of Monitoring Well}

The required number of monitoring wells and samples for each site largely depends on the site-specific conditions, including environmental risk posed by the site and the relative complexity of the geological and hydrological conditions. In general, each facility (Table 2 ) is required to have a minimum of three monitoring points, one up-gradient and two down-gradient (Fig. 1). However, larger operations with multiple livestock waste control facilities and sites located in sensitive groundwater area as well as areas with public health concerns may require more wells. Up-gradient wells provide the background conditions of the groundwater and so must be located far enough away from the facility. Down-gradient wells should be located very close to the facility to allow early detection of any possible contamination before it migrates far from the well site.

\section{Selection of Monitoring Parameters and Sampling Frequency}

Nitrogenous compounds are the main polluting components in livestock wastes with nitrate as the most serious concern. Nitrogen occurs in groundwater mainly in three forms as nitrates, nitrites, and ammonium ion. Nitrite and ammonium ions are intermediate and unstable forms of nitrogen and are quickly oxidized to the more stable nitrate [26]. Thus, nitrate is considered as an indicator parameter to assess the extent of pollution at the vicinity of a facility. Other parameters that indicate pollution are given in Table 3 and include ammonia, nitrite, $\mathrm{pH}, \mathrm{TDS}, \mathrm{P}, \mathrm{SO}_{4}{ }^{2-}$, and alkalinity. In addition, the selection of suitable monitoring frequency is essential in order to characterize the variability of the groundwater quality with time. In general, frequency of monitoring is based on the hydrogeological properties of 
Table 1 Groundwater monitoring criteria and parameters recommended by various governmental regulatory entities

\begin{tabular}{|c|c|}
\hline Country/place & Criteria \\
\hline Nebraska ${ }^{a}$ & $\begin{array}{l}\text { The decision on whether or not to recommend groundwater monitoring at a point source is based on the following: } \\
\text { - Depth to groundwater is shallow: }<50 \mathrm{ft} \\
\text { - Type of unsaturated sediments: sandy sediments } \\
\text { - If livestock facility is located in a public water supply's wellhead protection area } \\
\text { - If groundwater flows directly to a coldwater class A stream }\end{array}$ \\
\hline North Dakota ${ }^{\mathrm{b}}$ & $\begin{array}{l}\text { For open-lot cattle facilities } \\
\text { - If animals' number: } \geq 2000 \\
\text { - If production area: } \geq 20 \text { acres } \\
\text { For new or expanding concentrated animal feeding operation, if } \\
\text { - Soils: sandy loam, loamy sand, sand/ gravel } \\
\text { - Water supply well at a depth within } 30 \mathrm{ft} \text { of the ground surface } \\
\text { - The production area is within } 1 / 4 \text { mile of a neighboring private water supply well } \\
\text { - Within } 1 / 2 \text { mile of a non-community public water supply well or within } 1 \text { mile of a community public water supply well }\end{array}$ \\
\hline $\begin{array}{l}\text { New Mexico } \\
\text { Illinosis }^{\mathrm{d}}\end{array}$ & $\begin{array}{l}\text { Monitoring required for each potential source of groundwater contamination. However, the exact criteria for site selection is not mentioned. } \\
\text { Groundwater monitoring in accordance with following conditions: } \\
\text { If the uppermost aquifer material is located above or within } 20 \mathrm{ft} \text { of the lowest point of the planned lagoon bottom }\end{array}$ \\
\hline Minesota $^{\mathrm{e}}$ & Groundwater monitoring based on soil type and depth to water table; considered if the soil is sandy and depth of water table is $5 \mathrm{ft}$ or more \\
\hline Wyoming $^{\mathrm{f}}$ & $\begin{array}{l}\text { Monitoring requirement if: facility }<1 \text { mile from the drinking water intake or well; facility }<2 \text { miles but }>1 \text { mile from a drinking water intake } \\
\text { or well }\end{array}$ \\
\hline USEPA $^{g}$ & $\begin{array}{l}\text { Monitoring site considered: if the existing units and lateral expansions }<1 \text { mile from a drinking water intake; existing units and lateral } \\
\text { expansions }>1 \text { mile but }<2 \text { miles from a drinking water intake }\end{array}$ \\
\hline Wisconsin ${ }^{\mathrm{h}}$ & $\begin{array}{l}\text { Groundwater monitoring depending upon the type and strength of liquid waste, the volume of discharge, the type of land treatment system, the } \\
\text { rate of discharge to the land treatment system, and the site characteristics } \\
\text { of the land treatment system }\end{array}$ \\
\hline Manitoba ${ }^{\mathrm{i}}$ & $\begin{array}{l}\text { Monitoring wells are required where increased risk of groundwater contamination in areas where the subsoil underlying the storage consists of } \\
\text { sand, sand and gravel or shallow bedrock forming the aquifers, or sufficient clay or clay-till does not exist under the storage. }\end{array}$ \\
\hline Alberta ${ }^{\mathrm{j}}$ & Groundwater monitoring is based on hydrogeological assessment; however, the exact criteria are not known \\
\hline South Australiak, & $\begin{array}{l}\text { Groundwater monitoring is based on site geology, site hydrology, groundwater vulnerability and feedlot descriptions, and feedlot which has } \\
\text { potential to cause environmental pollution; however, the exact criteria are not known. }\end{array}$ \\
\hline British Columbia $^{\mathrm{m}}$ & Depend on site-specific geology, soil, and groundwater regime. However, the exact criteria are not known. \\
\hline UK, Ireland ${ }^{\mathrm{n}}$ & $\begin{array}{l}\text { The selection of monitoring locations will depend on the development of a conceptual model/understanding of the objectives for the body of } \\
\text { groundwater at risk. However, the exact criteria are not known. }\end{array}$ \\
\hline Queensland $^{\circ}$ & $\begin{array}{l}\text { Groundwater monitoring is recommended if: } \\
\text { - Highly permeable strata down to aquifer }(\mathrm{K}>10-6 \mathrm{~m} / \mathrm{s}) \\
\text { - Depth to groundwater }<5 \mathrm{~m} \\
\text { - }<200 \mathrm{~m} \text { from a water supply bore } \\
\text { - Over unconfined water supply aquifer }\end{array}$ \\
\hline
\end{tabular}

${ }^{\text {a }}$ Ground Water Monitoring at Livestock Waste Control Facilities in Nebraska

${ }^{\mathrm{b}}$ Livestock Program North Dakota Department of Health

${ }^{\mathrm{c}}$ Dairy Spefic Regulations New Mexico

${ }^{\mathrm{d}}$ Illinosis Livestock waste regulation

${ }^{\mathrm{e}}$ Minnesota Landfill guidance, MPCA

${ }^{\mathrm{f}}$ Wyoming Sanitary regulation, DEQ

${ }^{g}$ US EPA Groundwater Monitoring and Corrective Action

${ }^{\mathrm{h}}$ Wisconsin Legislative, document NR 214.21

${ }^{\mathrm{i}}$ Farm Practices Guidelines for Pig Producers in Manitoba, 2007

${ }^{\mathrm{j}}$ Farm Practices Guidelines for Pig Producers in Alberta, Farm Practices Guidelines for Pig Producers in Manitoba, 2007

${ }^{\mathrm{k}}$ Guidelines for Establishment and Operation of Cattle Feedlots in South Australia, 2nd Edition

${ }^{1}$ FSA Consulting, Feedlot Groundwater Investigation

${ }^{\mathrm{m}}$ Guidelines for Environmental Monitoring at Municipal Solid Waste Landfills, British Columbia

${ }^{\mathrm{n}}$ EU Water Framework Directive

${ }^{\circ}$ Waste disposal (ERA 60) Monitoring system, Department of Environmental and Resources Management, Queensland Government

aquifer and its susceptibility to pollution pressure. Table 3 notes that most guidelines require that the wells are monitored twice a year (usually, spring and fall). The frequency of groundwater monitoring should be reviewed regularly in response to the overall environmental performance of the site. In some cases, the 
Table 2 Selection of number of groundwater samples from monitoring sites recommended by various governmental regulatory entities

\begin{tabular}{|c|c|c|}
\hline Country/sites & No. of wells from up-gradient $(\mathrm{U})$ & No. of wells from down-gradient (D) \\
\hline Nebraska $^{a}$ & 1 (at least 300-500 ft away from LWCF) & 2 (very close to the LWCF) \\
\hline North Dakota ${ }^{\mathrm{b}}$ & 1 & 2 (add. may be required) \\
\hline Illinois ${ }^{\mathrm{c}}$ & 1 & 2 (around $20 \mathrm{ft}$ ) \\
\hline Minnesota $^{\mathrm{d}}$ & 1 & 2 (not farther than $200 \mathrm{ft}$ of the waste fill area) \\
\hline Wyoming $^{\mathrm{e}}$ & \multicolumn{2}{|l|}{ Minimum 3 wells from each facility } \\
\hline Wisconsin $^{\mathrm{f}}$ & 1 (far away from sites & $\begin{array}{l}2 \text { (at least around } 10 \mathrm{ft} \text { ), the department may } \\
\text { required more number of wells }\end{array}$ \\
\hline Canada $^{\mathrm{g}}$ & 1 & 3 \\
\hline South Australia ${ }^{\text {h }}$ & \multicolumn{2}{|c|}{$\begin{array}{l}\text { Moderate to high risk: } 1 \mathrm{U}, 2 \mathrm{D} \text { (groundwater between landfill and site boundary), } \\
\text { at least } 1 \text { for each receptor (groundwater between site and receptors at risk) }\end{array}$} \\
\hline British Columbia $^{\mathrm{i}}$ & 1 & 3 \\
\hline
\end{tabular}

${ }^{\text {a }}$ Livestock Waste Control Facilities (LWCF) in Nebraska

${ }^{\mathrm{b}}$ Livestock Program North Dakota Department of Health

${ }^{\mathrm{c}}$ Illinois Groundwater Monitoring regulation, Section 506.206

${ }^{\mathrm{d}}$ Landfill Site, Minnesota Pollution Control Agency

${ }^{\mathrm{e}}$ Solid Waste Guideline, Wyoming Department of Environmental Quality, Solid and Hazardous Waste Division

${ }^{\mathrm{f}}$ Wisconsin Legislative document NR. 214.21

${ }^{\mathrm{g}}$ Solid Waste, Govt. of Newfoundland and Labrador

${ }^{\mathrm{h}}$ Landfill site, EPA Guideline

${ }^{\mathrm{i}}$ Guidelines for Environmental Monitoring at Municipal Solid Waste Landfills agency may increase the frequency of sampling in response to identified poor environmental performance or within high risk zones.

\section{Management Guidelines}

The main sources of nitrate pollution in livestock areas include livestock yard (that includes barnyards, holding areas, and feedlots), manure storage lagoons, and cropland receiving manure [27] areas which are the main sources of animal wastes within livestock facilities. Improper management of these compartments results in manure loss, which then leaches into

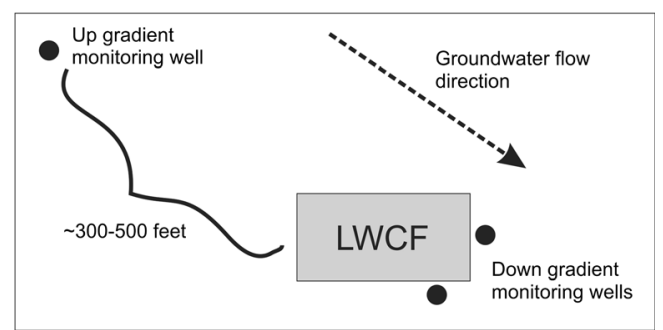

Fig. 1 Generic layout of a typical groundwater monitoring well at livestock waste control facility (LWCF) (Source: Livestock Waste Control Facilities (LWCF) in Nebraska) the subsurface and causes nitrate contamination of groundwater. Individual country or agency bodies handle this problem by formulating various management guidelines, which are discussed below.

\section{Livestock Yard}

Proper management of livestock yards includes selecting suitable sites and implementing effective maintenance that can reduce nitrate loss. Detailed requirements of this strategy, as based on the various regulations/guidelines (Table 4), are discussed below.

\section{Distance from Wells}

Table 4 shows that all livestock operations should be located at least 100-200 ft away from any wells to reduce the risk of water pollution. In the case of good farmstead planning, the livestock facility should be placed 300 to $400 \mathrm{ft}$ away from houses, because wells are often located near the house. In addition, livestock operations and/or exercise yards should be placed downslope from the well, so that the chance of runoff entering the well is reduced. 
Table 3 Selection of water parameters and sample frequency for groundwater monitoring recommended by various governmental regulatory entities

\begin{tabular}{|c|c|c|}
\hline Country/sites & Parameters & Frequency \\
\hline Nebraska $^{a}$ & Nitrate + nitrite, ammonia, total $\mathrm{N}, \mathrm{Cl}, \mathrm{SO}_{4}{ }^{2-}$ & Minimum two times per year \\
\hline North Dakota ${ }^{\mathrm{b}}$ & Nitrate, $\mathrm{Cl}^{-}$, ammonia, $\mathrm{N}$ isotope & At least twice a year, usually in the spring and fall (irrigation is not active) \\
\hline Illinois $^{\mathrm{c}}$ & $\begin{array}{l}\text { Nitrate-N, phosphate- } \mathrm{P}, \mathrm{Cl}^{-}, \mathrm{SO}_{4}{ }^{2-} \text {, ammonia } \mathrm{N}, \\
\text { Escherichia coli or Fecal coliform }\end{array}$ & Quarterly \\
\hline Minnesota $^{\mathrm{d}}$ & $\begin{array}{l}\text { Alkalinity, ammonia } \mathrm{N}, \text { nitrate }+ \text { nitrite, } \mathrm{SO}_{4}{ }^{2-} \\
\text { heavy metals, } \mathrm{EC} \text {, temperature, } \mathrm{pH}\end{array}$ & Routine sampling, limited to spring, summer and fall events \\
\hline South Australia ${ }^{\mathrm{e}}$ & $\begin{array}{l}\mathrm{pH}, \mathrm{EC}, \mathrm{TDS} \text {, nitrite }+ \text { nitrate, ammonia, } \\
\quad \text { heavy metals, } \mathrm{Ca}, \mathrm{Mg}, \mathrm{Na}, \mathrm{K}, \mathrm{Cl}^{-}, \mathrm{HCO}_{3}{ }^{-}, \mathrm{SO}_{4}{ }^{2-}\end{array}$ & Biannual \\
\hline Canada ${ }^{\mathrm{f}}$ & $\mathrm{pH}, \mathrm{EC}, \mathrm{TDS}$, ammonia, nitrate, nitrite, $\mathrm{P}, \mathrm{SO}_{4}{ }^{2-}$ & Biannual (spring and fall) \\
\hline
\end{tabular}

${ }^{a}$ Ground Water Monitoring at Livestock Waste Control Facilities

${ }^{\mathrm{b}}$ Livestock Program North Dakota Department of Health

${ }^{\mathrm{c}}$ Illinois Administrative rule, groundwater monitoring regulations around lagoons

${ }^{\mathrm{d}}$ Landfill Site, Minnesota Pollution Control Agency

${ }^{\mathrm{e}}$ Landfill Site EPA Guideline

${ }^{\mathrm{f}}$ Solid waste, Govt. of Newfoundland and Labrador

\section{Site Characterization}

Site topography, geology, and soil characteristics are factors in nitrate contamination of groundwater; surface/subsurface soil texture, soil depth, permeability, and water table are very important. According to Utah State University [28], the best sites are located on deep clay soils, although sites with well-drained silt loam/clay loam soil with low permeability are also appropriate. Sites characterized by shallow soil, or a high water table, or a sandy/gravelly soil with excessive drainage and high permeability are poor or unsuitable [29]. Soil type should be considered as one of the most important criteria for site selection.

\section{Clean Water Diversion and Runoff Control}

Reducing the amount of fresh water entering the livestock facility can reduce water pollution (Table 4). Diversion

Table 4 Guideline for livestock yards recommended by various US State governmental regulatory agencies

\begin{tabular}{|c|c|c|c|c|c|c|c|}
\hline Site/country & $\begin{array}{l}\text { Minimum distance } \\
\text { to well water }\end{array}$ & $\begin{array}{l}\text { Location } \\
\text { from well }\end{array}$ & $\begin{array}{l}\text { Site assessment } \\
\text { before development }\end{array}$ & $\begin{array}{l}\text { Clean water diversion/ } \\
\text { runoff control system }\end{array}$ & $\begin{array}{l}\text { Vegetative filter } \\
\text { strip system }\end{array}$ & Yard cleaning & Type of yard \\
\hline North Dakota ${ }^{a}$ & $\begin{array}{l}100 \mathrm{ft} \text { (private) } \\
500 \mathrm{ft} \text { (public) }\end{array}$ & Downslope & Yes & Yes & & & Concrete \\
\hline Virginia $^{b}$ & $150 \mathrm{ft}$ & Downslope & Yes & Yes & Yes & Once per week & Concrete \\
\hline Indiana $^{c}$ & $50 \mathrm{ft}$ (new well) & Downslope & Yes & Yes & Yes & Once per week & \\
\hline $\mathrm{Utah}^{\mathrm{d}}$ & $200 \mathrm{ft}$ & & Yes & Yes & & Once per week & \\
\hline Tennesee $^{\mathrm{e}}$ & $100 \mathrm{ft}$ & Downslope & Yes & Yes & Yes & Regularly & Concrete \\
\hline New Mexico ${ }^{f}$ & $\begin{array}{l}100 \mathrm{ft}(\text { private well) } \\
200 \text { (public well) }\end{array}$ & & Yes & Yes & Yes & & \\
\hline New Jersey ${ }^{g}$ & $50 \mathrm{ft}$ (new well); $200 \mathrm{ft}$ & Downslope & Yes & Yes & & & Concrete \\
\hline Nova Scotia ${ }^{\mathrm{h}}$ & $100 \mathrm{~m}$ & & Yes & Yes & Yes & & Concrete \\
\hline
\end{tabular}

${ }^{\text {a }}$ Livestock Program North Dakota Department of Health

${ }^{\mathrm{b}}$ Department of Environmental Quality, Virginia

${ }^{\mathrm{c}}$ Indiana State Board of Health, Livestock Yards Management

${ }^{\mathrm{d}}$ Utah State University Extension, Farmstead Assessment for Ground Water and Surface Water Protection, Fact Sheet 8, Revised March 2012

${ }^{\mathrm{e}}$ The University of Tennessee Agricultural Extension Service, US, Assessing Your Livestock Yard Management, Farm·A·Syst, SP484K

${ }^{\mathrm{f}}$ New Mexico FARM-A-SYST, Fact Sheet 8, Reducing the Risk of Groundwater Contamination by Improving Livestock Yards Management

${ }^{g}$ New Jersey FARM-A-SYST, Fact Sheet 8, Reducing the Risk of Groundwater Contamination by Improving Livestock Yards Management, NJFAS-8F

${ }^{\mathrm{h}}$ Sitting and Management of Hog Farms in Nova Scotia, Canada, N.S Dept. of Agriculture 
Fig. 2 Livestock yard management by diverting surface runoff and using vegetated filter strip (adopted from Utah Farmstread Assessment for Groundwater and Surface Water Protection, Uthan State

University Extension, Fact Sheet

8, Revised March 2012)

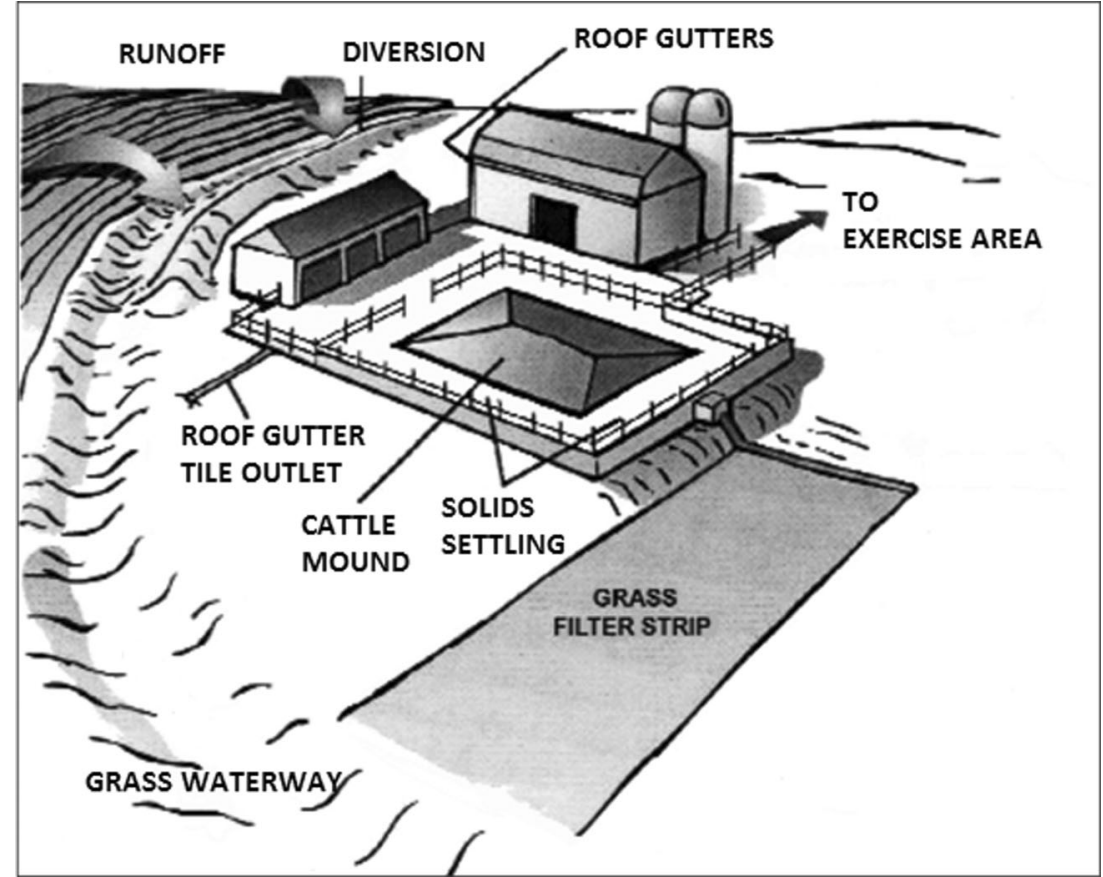

methods (Fig. 2) include small terraces and roof gutters to direct water away from livestock yards and constructing an earthen ridge or terrace across the slope upgrade from the livestock lot to prevent runoff from entering the yard. Vegetation filter strips (Fig. 2) are also effective to control pollutants within the runoff. It has been shown that the application of buffer strips also helps to minimize the pollutant inputs into water bodies around the livestock area [30]. Guidelines for these methods for some areas are given in Table 4.

\section{Yard Surface and Cleaning}

The risk of nitrate contamination in surface and groundwater can be somewhat controlled by the type of surface material. Generally, concrete is better than bare earth. In addition, if the bedrock is close to the surface, paving the surface with concrete will be helpful to reduce water contamination. Cleaning the livestock area on a regular basis can reduce the amount of manure in yard runoff. Based on the guidelines given in Table 4, cleaning and scraping at least once a week is preferable. Concrete surfaces are easier to clean than earthen surfaces, which can only be properly cleaned when dry, resulting in less frequent cleaning and increased potential for runoff.

\section{Abandoned Livestock Yard}

Abandoned yards can be a significant risk for nitrate contamination of groundwater. In abandoned yards, the manure pack breaks up easily due to lack of use, so that rain water can leach pass through the cracks, resulting in nitrate leaching to groundwater. To manage this problem, all the manure and soil mixture should be collected from the abandoned feedlot and then spread onto fields as fertilizer; the former feedlot surface can then be filled with other soil material. Afterward, the area should be planted with crops that require lots of nitrogen to make use of the nitrogen released from the manure decomposes.

\section{Manure Storage}

Proper storage of manure is crucial for every livestock operation to protect groundwater resources. The detailed requirements for manure storage in some areas are given below (Table 5).

\section{Distance from Wells}

Potential groundwater contamination by manure leachate can be more critical if the manure storage is located close to sources of drinking water or public wells. In order to minimize this risk, all manure storages must be located at the minimum setback distances as determined by different agencies with respect to any well. As shown in Table 5, the minimum separation distance should be between 30 and $90 \mathrm{~m}$ with $100 \mathrm{~m}$ a preferred distance to reduce risk. In addition, manure storage must be positioned downslope from wells so that runoff cannot drain into wells. The type of storage facility also dictates the preferred storage method. At Newfoundland, Canada [31], the minimum separation distance between manure storage and wells is $100 \mathrm{~m}$ for earthen storage but only $50 \mathrm{~m}$ for synthetic 
Table 5 Guidelines for management of manure storage facilities recommended by various governmental regulatory agencies

\begin{tabular}{|c|c|c|c|c|c|c|c|}
\hline Site/country & $\begin{array}{l}\text { Minimum distance } \\
\text { to well water }\end{array}$ & $\begin{array}{l}\text { Location } \\
\text { from well }\end{array}$ & $\begin{array}{l}\text { Site } \\
\text { assessment } \\
\text { before } \\
\text { development }\end{array}$ & $\begin{array}{l}\text { Distance } \\
\text { from waste } \\
\text { structure } \\
\text { bottom to } \\
\text { groundwater }\end{array}$ & $\begin{array}{l}\text { Surface } \\
\text { water } \\
\text { diversion }\end{array}$ & Liner material used & $\begin{array}{l}\text { Limits on } \\
\text { land } \\
\text { application }\end{array}$ \\
\hline Nebraska $^{a}$ & $\begin{array}{l}>100 \mathrm{ft} \text { (domestic) } \\
>1000 \mathrm{ft} \text { (public) }\end{array}$ & Downslope & Yes & $>4 \mathrm{ft}$ & Yes & Soil $\left(1 \times 10^{-7} \mathrm{~cm} / \mathrm{s}\right)$ synthetic liner & \\
\hline Illinois $^{\mathrm{b}}$ & $\begin{array}{l}>150 \mathrm{ft} \text { (potable } \\
\quad \text { water well) }\end{array}$ & & Yes & & Yes & $\begin{array}{l}\text { Concrete, earthen, and synthetic } \\
\text { liner for shallow aquifer }\end{array}$ & \\
\hline Missouri $^{\mathrm{c}}$ & $300 \mathrm{ft}$ & & Yes & & Yes & & \\
\hline Washington $^{\mathrm{d}}$ & $\begin{array}{l}100 \mathrm{ft} \\
250 \mathrm{ft} \text { (temporary) }\end{array}$ & Downslope & & & & & \\
\hline Texas $^{\mathrm{e}}$ & $150 \mathrm{ft}$ & Downslope & Yes & & Yes & $\begin{array}{l}\text { Clay liner with permeabliity } \\
1 \times 10^{-7} \mathrm{~cm} / \mathrm{s} \text {, concrete }\end{array}$ & \\
\hline California $^{\mathrm{f}}$ & $150 \mathrm{ft}$ & & Yes & & Yes & $\begin{array}{l}\text { Must contain at least } 10 \% \text { clay } \\
\text { and no more than } 10 \% \text { gravel } \\
\text { or materials of equivalent } \\
\text { impermeability }\end{array}$ & Yes \\
\hline Arizona $^{\mathrm{g}}$ & $100 \mathrm{ft}$ & & Yes & Varies & Yes & $\begin{array}{l}\text { Varies depending on soil types, } \\
\text { exposure, and NRCS technical } \\
\text { assistance and standards }\end{array}$ & Yes \\
\hline Ontario $^{\mathrm{h}}$ & $30 \mathrm{~m}$ & & Yes & & Yes & $\begin{array}{l}\text { Soil (hydraulic conductivity of } \\
1 \times 10-8 \mathrm{~m} / \mathrm{s} \text {, a geosynthtic } \\
\text { clay liner }\end{array}$ & Yes \\
\hline England $^{\mathrm{i}}$ & 100 & Downslope & Yes & & Yes & $\begin{array}{l}\text { Plastic liner, organic materials } \\
\text { such as leaves or woodships, } \\
\text { or concrete }\end{array}$ & Yes \\
\hline Prince Edward Island ${ }^{j}$ & $90 \mathrm{~m}$ & & Yes & $3.3 \mathrm{ft}$ & & Concrete, synthetic liner & Yes \\
\hline
\end{tabular}

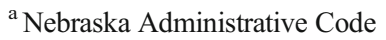

${ }^{\mathrm{b}}$ Illinosis Administractive Code, Section 900, Livestock Management Facility Regulations

${ }^{\mathrm{c}}$ Missouri Well Construction Code Rule 10 CSR 23-3.010, 1996

${ }^{\mathrm{d}}$ Clean Water for Washington: Managing Livestock Manure to Protect Groundwater, EB1717

${ }^{\mathrm{e}}$ Texas Agricultural Extension Service, Reducing the Risk of Groundwater Contamination by Improving Livestock Manure Storage and Treatment Facilities Report-B-6030

${ }^{\mathrm{f}}$ State Water Resources Control Board (statewide), CA Dept. of Food and Agriculture (CDFA), Regional Water Quality Control Boards (9 regions), Local Government

${ }^{g}$ Arizona Department of Environmental Quality (ADEQ)

${ }^{\text {h }}$ Ontario Regulation 267/03 under Nutrient Management Act, 2002, Sitting Regulations for Manure Storage Facilities, Order No. 09-061, 2009

${ }^{\mathrm{i}}$ Guideline for Livestock Yard and Manure Storage Management

${ }^{\mathrm{j}}$ Guideline for Manure Management for Prince Edward Island, Canada, Department of Agriculture and Forestry

or concrete storage. The groundwater contamination by manure leachate can be more critical if the manure storage is closely located to a drinking water/public well. Therefore, in order to minimize such risk, all manure storages must maintain the minimum setback distance with respect to any well.

\section{Site Characterization}

The location of manure storage facilities should consider geologic structure, soil texture, water table depth, and depth to bed rock. Livestock waste can easily contaminate groundwater if a storage facility is located in areas with thin soil, coarsetextured permeable soils, over sand or gravel aquifers, when the water table is at or near the surface, or if fractured bedrock/ karst terrain is within a few feet of the surface. Thus, hydrogeological characteristics of a site must be evaluated to ensure the site is suitable for storage; this is followed by many guidelines/regulations (Table 5).

\section{Use of Liners}

Liners are commonly used at storage pits or lagoons to control leachate; the choice of liner depends on multiple factors. According to Illinois Administration Code 506 [32], if groundwater is located near (within $1.5 \mathrm{~m}$ ) the bottom of the proposed waste storage facility, it must be constructed from concrete to prevent seepage. If the facility is constructed from earthen material, it should also have an earthen or synthetic 
Table 6 List of countries/states followed action plan for the management of water pollution

\begin{tabular}{|c|c|}
\hline Country/place & Management action \\
\hline North Dakota ${ }^{a}$ & $\begin{array}{l}\text { - If one sample result of a groundwater monitoring well exceeds the monitoring action limit, an additional sample from that well } \\
\text { shall be taken within } 30 \text { days. } \\
\text { - If the maximum level action limit is reached, the department may require the facility to remove all manure from the area, which } \\
\text { has been determined to be the source of contamination, and upgrade the facility and mitigate the source of contamination. }\end{array}$ \\
\hline Illinois $^{\mathrm{b}}$ & $\begin{array}{l}\text { For violations of the setback distance requirements, the Department may issue one of the following to the owner or operator of the } \\
\text { livestock management facility or livestock waste handling facility: } \\
\text { - If during construction, a cease and desist order which prohibits further construction of the livestock management facility or } \\
\text { livestock waste handling facility prohibits entry of livestock into the livestock management facility and prohibits use of the } \\
\text { livestock waste handling facility; or an operational cease and desist order. } \\
\text { Waste management plan: } \\
\text { Any person who is required to prepare a waste management plan and who fails to do so shall be subject to the following: } \\
\text { - Warning letter by the Department for the first violation and shall be given } 30 \text { working days to do that. } \\
\text { - For failure to maintain and implement within } 30 \text { working days, the person shall be fined an administrative penalty of up to } \$ 1000 \\
\text { by the Department and given to do another } 30 \text { days. } \\
\text { - For failure to maintain after the second } 30 \text {-day period, the Department may issue an operational cease and desist order until } \\
\text { compliance is attained. }\end{array}$ \\
\hline Ohio $^{c}$ & $\begin{array}{l}\text { Livestock operations found to be discharging pollutants to the state's water without a valid permit might be liable for civil penalties } \\
\text { up to } \$ 10,000 \text { for each day of violation. }\end{array}$ \\
\hline Ohio $^{d}$ & $\begin{array}{l}\text { Anyone found to be discharging pollutants such as manure, including process wastewater, to the state's waters can be found in } \\
\text { violation of the Stream Litter Act, which carries penalties of a third-degree misdemeanor for a first offense. Violators can be fined } \\
\text { up to } \$ 500 \text {, or sentenced to } 60 \text { days in jail, or both, for a first offense. } \\
\text { Corporations can be fined up to } \$ 3000 \text { for a first offense and } \$ 5000 \text { for subsequent offenses. }\end{array}$ \\
\hline Hawaii $^{\mathrm{e}}$ & $\begin{array}{l}\text { Each CAFO (concentrated animal feeding operation) is required to have a National Pollution Discharge Elimination System } \\
\text { (NPDES) permit, if it falls under any of three criteria: } \\
\text { - Any animal feeding operation having over } 1000 \text { animal units. } \\
\text { - Any animal feeding operation having over } 300 \text { animal units, and which discharges process waste pollutants directly into state } \\
\text { waters through a manmade device, or otherwise come into direct contact with the animals confined in the operation. } \\
\text { If the CAFO does not have an NPDES permit, any discharge occurring from the operation is a violation of the Federal Clean Water } \\
\text { Act. The operation is thereby subject to enforcement action under the pollution reduction program by the Director of Health } \\
\text { Official. It is accompanied with an order to cease and desist from any further violation and may specify corrective measures and } \\
\text { the time schedule for their implementation. A formal action also usually contains an order for the payment of a civil penalty. }\end{array}$ \\
\hline Nebraska $^{\mathrm{f}}$ & $\begin{array}{l}\text { Any person owning or operating an animal feeding operation which does not hold an NPDES, Nebraska Department of } \\
\text { Environmental Quality, required inspection request with the appropriate fee as follows: } \\
\text { - } \$ 100 \text { for each small animal feeding operation; } \\
\text { - } \$ 200 \text { for each medium animal feeding operation; or } \\
\text { - \$500 for each large animal feeding operation. }\end{array}$ \\
\hline
\end{tabular}

North Carolina $^{\mathrm{g}} \quad$ A livestock farm operator may be fined up to $\$ 5000$ immediately for a wilful or deliberate discharge of pollutants to surface waters of the state

South Australia $^{\mathrm{h}} \quad$ If liquid waste is placed into, or allowed to enter or form, a pond or lagoon in(whether natural or artificial) where it would be subject to evaporation or percolation into the earth, the licensee is guilty of an offence, penalty $\$ 2000$

Hong Kong Waste ${ }^{\mathrm{i}}$ Any person who failed containers for storage of livestock waste that spillage, leachage of any livestock waste contained therein, and who discharge solid or liquid waste into any channel, ditch, communal sewer, spring, watercourse, well for potable or public shall be liable a fine of $\$ 50,000$

${ }^{\text {a }}$ Livestock Program, North Dakota Department of Health

${ }^{\mathrm{b}}$ Illinois Administrative Code 900: Livestock Management Facility Regulations

${ }^{\mathrm{c}}$ Ohio Administrative Code 901

${ }^{\mathrm{d}}$ Ohio Department of Natural Resources, Division of Wildlife

${ }^{\mathrm{e}}$ Hawaii State Department of Health Wastewater, Guidelines Livestock Waste Management

${ }^{\mathrm{f}}$ Administrative Code - Nebraska Department of Environment Quality

${ }^{\mathrm{g}}$ North Carolina, Water Quality and Waste Management Rules for Livestock Farms

${ }^{\mathrm{h}}$ South Australia,Waste Management Regulations, 1988

${ }^{\mathrm{i}}$ Hong Kong Waste Disposal (Livestock Waste) Regulations, Cap 35A

liner. The earthen liner should be in situ soil to which additives such as clay or clay/bentonite mixtures are added, with a minimum thickness of $0.66 \mathrm{~m}$. Several guidelines/regulations are given in Table 5. In addition, manure storage facility should include a compacted soil cover to seal the site. This will reduce oxygen contact and lessen aerobic decomposition, which 
promotes microbial conversion of nitrate to nitrogen gas, which escapes to the atmosphere and reduces nitrate leaching to groundwater. In the case of karst topography, the facility should be constructed utilizing a rigid material such as concrete or steel to prevent seepage of the stored material into groundwater [32].

\section{Limit of Manure Application}

Livestock manure is a valuable fertilizer. However, the amount of manure produced on livestock farms is often more than agronomic requirements of the farm, which can lead to repeat application of manures in excess of crop requirements and a surplus N [33]. A study of 177 Dutch daily farms showed an average $\mathrm{N}$ surplus of $486 \mathrm{~kg} \mathrm{~N} \mathrm{ha}^{-1}$ [34]. Similarly, excess N surpluses at dairy, pig, and poultry farms have been reported from other European countries [35]. This excess $\mathrm{N}$ is a potential major source of nitrate in groundwater. [36] reported high nitrate contamination in groundwater in Delaware where cropland received excessive application of livestock manure. To cope with this problem, guidelines/regulations restrict the application of manures on crops. The European Commission Nitrates Directive [37] has set $170 \mathrm{~kg}$ of nitrogen per hectare per year for regions that are prone to $\mathrm{N}$ leaching.

In addition, manure application is restricted with respect to public water well locations and water table depth. According to Hawaii Guidelines for Livestock Waste Management [38], livestock waste should not be applied to land within $50 \mathrm{ft}$ of drinking water wells. In many countries, manure application is avoided at certain times of the year, mostly immediately before, during, and after high rainfall and during flooding condition. Also, proper concerns must be given to soil types before applying manure, for example, soil with coarse textured soils, fractured bedrock, and low water holding capacity [39]. These sites have high potential for leaching, thus they can cause serious nitrate pollution in groundwater [40]. According Nova Scotia guideline [41], manure should not be applied within $60 \mathrm{~m}$ on a sand or gravel soil. Also, manure application should be avoided to frozen or snow-covered soil.

\section{Action Plan}

Action plans for responding to $\mathrm{N}$ pollution, prevention, and penalties for non-compliance have been determined by numerous countries/states (Table 6). In most cases, the plans deal with the following:

- Monitoring nitrate and reporting the results

- Comply with the regulation and determine contaminant levels

- Action required if nitrate exceeds permissible limits

- Warning in the case of first-time violation
- Action (fine or penalty) when warning is ignored

- Informing the public about water quality and public health risks

\section{Conclusions}

Intensive livestock production is a major environment concern of nitrate contamination in groundwater. There are several monitoring and management guidelines/legislations developed in many advanced countries/states to combat this contamination, but there is no single model that can be universally applied because each state has its own, and sometimes complex, guidelines. However, existing guidelines can be adopted or used as a model, where none currently exists. Effective monitoring includes site selection criteria along with selection of sampling points and parameters which can identify the source and extent of the contamination. In most of the US states, the site is selected based on groundwater depth, well location in relation to livestock manure storage areas and surface and subsurface soil texture, and number of livestock. In other countries, it is based more on conceptual modeling. Management programs deal with selection of suitable location (based on the surface/ subsurface geological conditions, minimum setback distance, downslope location from wells), proper structure (use of liners and diversion of surface runoff from facility), maintenance of the facility, and limits of manure application, in order to reduce nitrate leaching. In addition, an action plan should be implemented in state level to regulate contamination levels. Awareness and training programs on best livestock management practices should be given to the public, including farming communities, to reduce nitrogenous inputs to groundwater resources.

\section{Compliance with Ethical Standards}

Conflict of Interest On behalf of all authors, the corresponding author states that there is no conflict of interest.

Human and Animal Rights and Informed Consent No human or animal studies are performed by the authors. This article does not contain any studies with human or animal subjects performed by any of the authors.

\section{References}

1. Sugimoto Y, Hirata M. Nitrate concentration of groundwater and its association with livestock farming in Miyakonojo Basin, southern Kyushu, Japan. Jpn Soc Grassland Sci. 2006;52:29-36.

2. Roy S, Speed C, Bennie J, Swift R, Wallace P. Identifying the significant factors that influence temporal and spatial trends in nitrate concentrations in the Dorset and Hampshire Basin Chalk 
aquifer of Southern England. Q J Eng Geol Hydrogeol. 2007;40: 377-92.

3. Kim K, Yun S, Choi B, Chae G, Joo Y, Kim K. Hydrochemical and multivariate statistical interpretations of spatial controls of nitrate concentrations in a shallow alluvial aquifer around oxbow lakes (Osong area, central Korea). J Contam Hydrol. 2009;107:114-27.

4. Wongsanit J, Teartisup P, Kerdsueb P, Tharnpoophasiam P, Worakhunpiset S. Contamination of nitrate in groundwater and its potential human health: a case study of lower mae Klong river basin. Thail Environ Sci Pollut Res. 2015;22:11504-12.

5. Höring $\mathrm{H}$, Chapman D. Nitrates and nitrites in drinking water, World Health Organization Drinking Water Series. London: IWA Publishing; 2004.

6. Thompson RB, Martinez-Gaitan C, Gallardo M, Gimenez C, Fernandez MD. Identification of irrigation and $\mathrm{N}$ management practices that contribute to nitrate leaching loss from an intensive vegetable production system by use of a comprehensive survey. Agr icWater Manag. 2007;89:261-74.

7. Dahan O, Babad A, Lazarovitch N, Russak EE, Kurtzman D. Nitrate leaching from intensive organic farms to groundwater. Hydrol Earth Syst Sci. 2014;18:333-41.

8. Hooda PS, Edwards AC, Anderson HA, Miler A. A review of water quality concerns in livestock farming areas. Sci Total Environ. 2000;250:143-67.

9. Wakida FT, Lerner DN. Non-agricultural sources of groundwater nitrate: a review and case study. Water Resourc. 2005;39:3-16.

10. Rivett MO, Smith JWN, Buss SR, Morgan P. Nitrate occurrence and attenuation in the major aquifers of England and Wales. Q J Eng Geol Hydrogeol. 2007;40:335-52.

11. Hallberg GR, Keeney DR. Nitrate, Alley. In: William A, editors. Regional ground-water quality, Van nostrand Reinhold, New York; 1993. p.297-322.

12. Erickson D. Ground water quality assessment, Whatcom County dairy lagoon \#2, Lynden, Washington. Washington state department of ecology, open-file report; 1992. 26 p.

13. Schans ML, Harter T, Leijinse A, Mathews M, Meyer R. Characterizing sources of nitrate leaching from an irrigated dairy farm in Merced County, California. J Contam Hydrol. 2009;110:9-21.

14. Olson BM, Miller JJ, Rodvang J, Yanke LJ. Soil and Groundwater quality under a cattle feedlot in Southern Alberta. Water Qual Res J Can. 2005;40:131-44.

15. Infascelli R, Pelorosso R, Lorenzo B. Spatial assessment of animal manure spreading and groundwater nitrate pollution. Geospat Health. 2009;4:27-38.

16. Giammarino M, Quatto P. Nitrate in drinking water: relation with intensive livestock production. J Prev Med Hyg. 2015;56(4):E187-9.

17. Delgado C, Rosegrant M, Steinfeld H, Ehui S, Courbois C. Livestock to 2020: The next food revolution. Food Agriculture and Discussion Paper No. 28. International Food Policy Research Institute, Food and Agriculture Organization, International Livestock research Institute. 1999. (Source: http://www.fao.org/ ag/AGA/LSPA/lvst2020/Default.htm).

18. Gerber P, Chilonda P, Franceschini G, Menzi H. Geographical determinants and environmental implications of livestock production intensification in Asia. Bioresour Technolol. 2005;96:263-76.

19. Steinfeld H, Chilonda P. Old players, new players, Livestock Report 2006. Rome: Animal Production and Health Division, Food and Agriculture Organization of the United Nations; 2006. p. 3-14.

20. Lokesh L. A study of nitrate contamination in groundwater of Delhi, India. Asian J Water Environ Pollut. 2013;10:91-4.

21. Gollenhon N, Margriet C. Confined animal production poses manure management problems, Agricultural Outlook 2000; 12-18.
22. Sloan AJ, Giliam JW, Parsons JE, Mikkelsen RL, Riley RC. Groundwater nitrate depletion in swine lagoon effuluent-irrgated pasture and adjacent riparian zone. J Soil Water Cons. 1999;54:651-6.

23. Gerber P, Menzi H. Nitrogen losses from intensive livestock farming systems in Southeast Asia: a review of current trends and mitigation options. Volume 1293, July 2006, Pages 253-261.Greenhouse Gases and Animal Agriculture: An Update. Proceedings of the 2nd International Conference on Greenhouse Gases and Animal Agriculture, held in Zurich, Switzerland between 20 and 24 September 2005 .

24. US EPA (U.S Environmental Protection Agency) 2003. National primary drinking water standards: U.S Environmental Protection Agency.

25. World Health Organization. Recommendations; nitrate and nitrite. p. 417-420. In Guidelines for drinking-water quality, 3rd ed. WHO: Geneva; 2004.

26. Keeney DR. Sources of nitrate to groundwater. Crit Rev Environ Control. 1986;16:257-304.

27. Harter TH, Davis MC, Mathews MC, Meyer RD. Shallow groundwater quality on dairy farms with irritated forage crops. J Contam Hydrol. 2002;55:287-315.

28. Utah Farmstead Assessment for Ground Water and Surface Water protection. Fact Sheet 8, WQFA-15. 2005. (Source: http:// extension.usu.edu/files/factsheets/FAS8_livestock_factsheet.pdf).

29. WQ658, Reducing the risk of groundwater contamination by site evaluation. University of Missouri Extension Publication (Source: $\mathrm{http}: / /$ extension.missouri.edu/p/WQ658).

30. Clausen JC, Meals Jr DW. Water quality achievable with agricultural best management practices. Joil Water Conse. 1989;44:593-6.

31. A factsheet series on Environmental guidelines for livestock producers. Publication SLM045, 2002. Newfoundland and Labrador (Source: http://www.faa.gov.nl.ca/agrifoods/land/envseries/pdf/fs livestock.pdf).

32. Livestock waste regulations. Illinois Administrative Code 506 (Source: https://www.agr.state.il.us/Environment/LMFA/ lmfaconstruct.pdf).

33. Chang C, Entz T. Nitrate leaching looses under repeated cattle feedlot manure applications in southern Alberta. J Environ Qual. 1996;25:145-53.

34. Nolan BT. Relating nitrogen sources and aquifer susceptibility of nitrate in shallow ground waters of the United States. Ground Water. 2001;39:290-9.

35. Jarvis SC. Nitrogen cycling and losses from dairy farms. Soil Use Manag. 1993;9:99-104.

36. Andres AS. Nitrate loss via flow, coastal Sussex County, Delaware. In: Steele K, editor. Animal waste and the land-water interface. New York: Lewis Publishers; 1995. p. 69-76.

37. Directive of the Council of December 12, 1991. Concerning the protection of waters against pollution caused by nitrates from agricultural sources (91/676/EEC). Brussels: European Commission; 1991. p. 1-8.

38. Appendix for livestock waste management guideline, University of Hawaii-Manoa, 2010. (Source: http://health.hawaii.gov/ wastewater/files/2013/06/livestock_appendix.pdf).

39. Zhao Z, Knowlton NGL. Hormones in waste from animal concentrated animal feeding operations. In: Aga DS, editor. Fate and transport of pharmaceuticals in the environment and water treatment system. 1st ed. Boca Raton: CRC Press; 2008. p. 291-329.

40. Fraters D, Boumans LJM, Drecht GV, Hann TD, Hoop WD. Nitrate monitoring in groundwater in the sandy regions of the Netherlands. Environmental Pollution. 1998;102(S1):479-85.

41. Manure management guidelines. Nova Scotia Agriculture. 2006 (Source: http://novascotia.ca/thinkfarm/documents/manureguide 2006lowres.pdf). 